\title{
TRAIT KEPRIBADIAN BIG FIVE DAN SIKAP GURU TERHADAP PENDIDIKAN INKLUSIF SEKOLAH DASAR
}

\author{
Fellianti Muzdalifah * Sarah Hikmah Fazrina ** \\ * Program Studi Psikologi, Universitas Negeri Jakarta \\ ** Program Studi Psikologi, Universitas Negeri Jakarta
}

DOI: https://doi.org/10.21009/JPPP.051.06

\author{
Alamat Korespondensi: \\ fmuzdalifah@unj.ac.id \\ shfazrina3@gmail.com
}

\begin{abstract}
This study aims to understand the influence of teacher personality on teacher attitudes toward inclusive education. The variables studied were the big five personalities as an independent variable $(X)$ and teacher attitudes toward inclusive education as a dependent variable (Y). The method used is quantitative research, with cluster sampling technique. Participants of this study were teachers from inclusion public elementary school in Jakarta $(N=133)$. The instrument used to measure teacher personality is Big Five Inventory (BFI), while Multidimensional Attitudes toward Inclusive Education Scale (MATIES) was used to measure teacher attitudes toward inclusive education. Processing methods of data analysis in hypothesis testing using multiple regression analysis. Results of this study showed there is no influence of teacher personality on teacher attitudes toward inclusive education $(p<\alpha ; 0,113<0,05)$. Therefore, in this study Ho is accepted and Ha rejected.
\end{abstract}

Keywords

teacher personality, big five personality, teacher attitudes, inclusive education

\section{Pendahuluan}

Pemerintah telah memberikan berbagai jenis pendidikan bagi anak yang memiliki kebutuhan khusus yaitu sekolah luar biasa, sekolah integrasi dan sekolah inklusi. Sekolah inklusi merupakan sekolah yang menyelenggarakan pendidikan inklusif. Berdasarkan Peraturan Menteri Pendidikan Nasional Republik Indonesia Nomor 70 Tahun 2009 Pasal 1, pendidikan inklusif adalah sistem penyelenggaraan pendidikan yang memberikan kesempatan kepada semua peserta didik yang memiliki kelainan dan memiliki potensi kecerdasan dan/atau bakat istimewa untuk mengikuti pendidikan atau pembelajaran dalam satu lingkungan pendidikan secara bersama-sama dengan peserta didik pada umumnya. Sekolah inklusi sekarang sudah ada di berbagai provinsi salah satunya adalah provinsi DKI Jakarta. Berdasarkan data dinas pendidikan provinsi DKI Jakarta tahun 2015, terdapat 371 sekolah negeri inklusi yang mencakup jenjang taman kanak- kanak, sekolah dasar, sekolah menengah pertama, sekolah menengah atas, dan sekolah menengah kejuruan yang tersebar di 42 kecamatan di kota administrasi Jakarta Timur, Jakarta Barat, Jakarta Utara, Jakarta Selatan dan Jakarta Pusat.

Berdasarkan data dinas pendidikan provinsi DKI Jakarta tersebut, jumlah sekolah negeri inklusi terbanyak adalah jenjang sekolah dasar yaitu 260 sekolah. Jumlah tersebut membuktikan bahwa pemerintah peduli terhadap pendidikan untuk anak berkebutuhan khusus. Banyaknya sekolah negeri inklusi jenjang sekolah dasar tersebut juga membuktikan bahwa sekolah dasar 
merupakan jenjang pendidikan formal pertama untuk peserta didik, sehingga peristiwa- peristiwa penting dalam tumbuh kembang anak berkebutuhan khusus dan pembelajaran pertama mereka terjadi saat mereka mengenyam bangku pendidikan sekolah dasar. Kegiatan belajar mengajar di sekolah dasar juga didominasi oleh guru kelas atau dahulu sering disebut dengan wali kelas, sehingga intensitas guru kelas berkomunikasi dengan anak berkebutuhan khusus juga sangat sering. Berkembangnya jumlah sekolah negeri inklusi jenjang sekolah dasar tersebut, kurang diiringi dengan perkembangan kualitas dari sekolah negeri inklusi.

Menurut Mujidto, dkk (2012) belum siapnya sekolah melakukan penyesuaian pada pendidikan inklusif berkaitan dengan ketersediaan sumber daya manusia yang belum memadai, keterbatasan jumlah guru pendamping khusus yang mendampingi anak berkebutuhan khusus dalam proses pembelajaran, serta rendahnya dukungan warga sekolah dan masyarakat terhadap pendidikan anak berkebutuhan khusus tersebut. Hal tersebut juga didukung oleh Ilahi (2013) yang mengatakan faktor yang menentukan keberhasilan pendidikan inklusif yang tidak kalah penting adalah tenaga pendidik atau guru yang profesional dalam bidangnya untuk membina dan mengayomi anak berkebutuhan khusus, sehingga tenaga pendidik diharapkan memiliki kualifikasi yang dibutuhkan seperti memiliki pengetahuan, keterampilan, sikap tentang materi yang diajarkan dan memahami karakteristik siswa. Tenaga pendidik yang tidak memiliki kualifikasi tersebut dapat menjadi salah satu faktor yang akan menghambat berjalannya pendidikan inklusif.

Selain hal tersebut, United Nations Educational, Scientific, and Cultural Organization (UNESCO) menilai bahwa sikap guru juga dapat menjadi hambatan utama dalam pendidikan inklusif. Apabila guru tidak memiliki sikap yang positif terhadap siswa berkebutuhan khusus, maka tidak mungkin anak-anak tersebut dapat menerima pendidikan yang layak (www. unescobkk.org). Berdasarkan hal tersebut, sikap yang dimiliki oleh guru terhadap pendidikan inklusif, baik sikap yang positif maupun negatif dapat berdampak pada proses kegiatan pembelajaran peserta didik.
Forlin \& Chambers (2011) juga memastikan bahwa pandangan dan sikap guru sering menentukan keberhasilan dari integrasi lebih dari pengetahuan profesional dan persiapan formal mereka. Sikap guru telah ditemukan sangat terkait terhadap keberhasilan pendidikan inklusif (Avramidis \& Norwich, 2002 dalam Costello \& Boyle, 2013). Sikap adalah suatu reaksi evaluatif yang menyenangkan atau tidak menyenangkan terhadap sesuatu atau seseorang (Eagly \& Chaiken, 2005 dalam Myers, 2014). Sikap juga didefinisikan sebagai keadaan batin seseorang, mempengaruhi orang tersebut untuk respons yang menyenangkan jika sikapnya positif dan untuk respons yang tidak menyenangkan jika sikapnya negatif, jadi mempengaruhi perilaku orang tersebut kedepannya (Eagly, 1992 dalam Galovic et al, 2014). Hal tersebut dapat menjelaskan sikap guru terhadap pendidikan inklusif dapat dinilai secara positif atau negatif. Seorang guru yang memiliki sikap negatif terhadap pendidikan inklusif akan menjalankan program tersebut dengan berat hati dan memandang anak berkebutuhan khusus tersebut sebagai beban yang mereka hadapi, sedangkan seorang guru yang memiliki sikap positif terhadap pendidikan inklusif akan menerima program pemerintah tersebut dan akan berusaha untuk meningkatkan kompetensi dirinya agar pendidikan inklusif tersebut dapat berjalan dengan efektif.

Hal tersebut juga sudah dibuktikan bahwa beberapa guru yang memegang sikap yang lebih positif terhadap pendidikan inklusif dan dapat menjadi lebih sensitif dan fleksibel ketika mengajar anak dengan kebutuhan khusus (Fairbanks et al, 2010 dalam Bukovec et al, 2016), sedangkan guru yang memiliki sikap negatif terhadap pendidikan inklusif jarang menggunakan strategi yang diketahui berhasil di lingkungan pendidikan (Bender et al, 1995 dalam Galovic et al, 2014) oleh karena itu siswa dengan kebutuhan khusus sedikit berhasil di dalam kelas yang diajarkan oleh guru yang memiliki sikap negatif terhadap pendidikan inklusif (Ellins \& Porter, 2005 dalam Galovic et al, 2014). Hal tersebut membuktikan bahwa peran guru pendidikan umum menjadi penting untuk keberhasilan dalam mengimplementasikan pelaksanaan pendidikan inklusif, sehingga penting untuk meneliti sikap guru pendidikan umum tentang inklusi sebagai peningkatan 
peran guru di dalam konteks ruang kelas (Tsakiridou \& Polyzopoulou, 2014).

Berkaitan dengan sikap, faktor yang memengaruhi sikap guru terhadap pendidikan inklusif menurut Avramidis dan Norwich (dalam Erisa \& Wrastari, 2013) yaitu siswa; konsep guru terhadap siswa berkebutuhan khusus biasanya bergantung pada jenis hambatan siswa, tingkat keparahan hambatan siswa, dan kebutuhan siswa akan pendidikan, guru; terbagi dalam beberapa variabel yaitu gender, usia, pengalaman mengajar, tingkat kelas yang diajar, pengalaman kontak dengan siswa berkebutuhan khusus, pelatihan, keyakinan guru, dan pandangan sosio-politik, dan lingkungan pendidikan; ketersediaan dukungan fasilitas di dalam kelas dan level sekolah. Faktor pengalaman mengajar diperkuat dengan hasil wawancara informal yang dilakukan oleh penulis terhadap dua subjek guru yang mengajar di Sekolah Dasar Negeri Inklusi di Jakarta. Kedua subjek tersebut memiliki pengalaman yang berbeda dengan pendidikan inklusif, subjek pertama merupakan fresh graduate yang baru mengajar satu semester di sekolah inklusi, dan subjek kedua telah mengajar empat tahun di sekolah inklusi dan sebelumnya memiliki pengalaman mengajar di Sekolah Laboratorium UNJ yang juga menangani anak berkebutuhan khusus di daerah Setiabudi. Ketika subjek dihadapkan dengan tingkah anak berkebutuhan khusus dikelas, subjek pertama mengaku anak berkebutuhan khusus tersebut sangat mudah memancing emosi dirinya dan memecah konsentrasi beliau. Subjek kedua mengatakan ketika menghadapi anak tersebut, beliau harus tegas, banyak sabar dan meningkatkan komunikasi dengan orang tua dari anak tersebut.

Hal tersebut juga relevan dengan Avramidis dkk (dalam Bukovec dkk., 2016) yang menemukan bahwa sikap terhadap pendidikan inklusif lebih positif pada guru yang memiliki pengalaman sebelumnya dengan proses inklusi. Penelitian lain juga menunjukkan bagaimana pengalaman guru memiliki pengaruh terhadap pendidikan inklusi atau anak berkebutuhan khusus itu sendiri. Hal ini relevan dengan hasil penelitian dari Anderson, Watt, Nobley dan Shanley (2012) bahwa guru yang memiliki pengalaman yang meningkat, mereka memiliki sikap yang menyenangkan ketika mengajar siswa dengan ADHD. Hasil penelitian Tsakiridou \& Polyzopoulou (2014) juga menyatakan bahwa guru yang telah mengikuti program pendidikan khusus tampaknya lebih bersedia untuk menerima siswa berkebutuhan khusus di kelas reguler.

Faktor yang mempengaruhi terbentuknya sikap dapat berasal dari internal (faktor yang terdapat dalam diri orang yang bersangkutan) maupun eksternal (faktor yang terdapat dari luar diri orang yang bersangkutan seperti sifat objek, kewibawaan, sikap orang-orang yang mendukung sikap tersebut, media komunikasi yang digunakan dalam menyampaikan sikap, dan situasi saat sikap itu dibentuk) (Sarwono, 2009). Jika dilihat dari faktor internal, kepribadian dari individu tersebut dapat menjadi pengaruh terbentuknya sikap tersebut. Sobur (2009) juga mengatakan bahwa sikap seseorang ditentukan oleh keadaan kepribadiannya. Kepribadian seseorang dapat mempengaruhi bagaimana orang tersebut bersikap dan berperilaku. Menurut Todorovic, Stojiljkovic, Djigic dan Ristanic (2012) karakteristik pribadi yang dimiliki oleh seorang guru adalah jenis perlengkapan tertentu yang dimiliki oleh guru untuk bekerja di dalam kelas dan untuk mentransfer pengetahuan, kemampuan sosial dan nilai moral melalui proses pendidikan. Kepribadian menurut Allport (dalam Feist \& Feist, 2006) adalah organisasi dinamis didalam sistem psikofisis individu dimana yang menentukan karakteristik unik dan khas dalam berperilaku dalam upaya menyesuaikan diri dengan lingkungannya.

Salah satu teori yang menjelaskan kepribadian menggunakan pendekatan teori Big Five Personality atau Five-Factor theory of Personality. Jenis-jenis kepribadian yang termasuk ke dalam teori ini ada 5 yaitu, openness to experience yaitu proaktif mencari dan menghargai pengalaman karena keinginannya sendiri, toleran dan melakukan eksplorasi terhadap sesuatu yang belum dikenal, yang kedua conscientiousness yaitu derajat keteraturan individu, tekun, dan motivasi yang berorientasi pada tujuan, kemudian ada extraversion yang merujuk pada kuantitas dan intensitas interaksi personal, tingkat aktivitas, kebutuhan akan stimulasi dan kapasitas untuk mendapatkan kesenangan, keempat agreeableness merujuk pada kualitas orientasi interpersonal seseorang dimulai dari perasaan peduli sampai dengan perasaan permusuhan dalam pikiran, perasaan, dan tindakan, dan yang terakhir yaitu 
neuroticism yang mengidentifikasikan kecenderungan individu untuk mengalami distress psikis, ide-ide yang tidak realistik dan coping respon yang maladaptive.

Berdasarkan hasil penelitian Todorovic, dkk (2012) yang menunjukkan bahwa $80 \%$ dari orang yang diuji mendukung pendidikan inklusif dan hanya trait kepribadian openness yang memiliki korelasi yang signifikan dengan sikap yang positif terhadap pendidikan inklusif, kemudian penelitian Falzon dkk (2015) yang menunjukkan bahwa trait personality neuroticism memiliki hubungan yang positif dan signifikan dengan internalization of thinness norms dan memiliki hubungan yang negatif dengan regulasi diri terhadap sikap makan. Selanjutnya trait kepribadian agreeableness memiliki hubungan yang positif dan signifikan dengan regulasi diri terhadap sikap makan, dan penelitian Walker dan Christopher (2016) yang menunjukkan bahwa conscientiousness, extraversion, dan agreeableness secara positif memprediksi sikap dan perilaku sarapan yang sehat, neuroticism secara positif memprediksi sikap dan perilaku sarapan yang tidak sehat, dan orangorang dengan preferensi pagi cenderung makan lebih sehat.

Berdasarkan apa yang telah dipaparkan mengenai sikap guru terhadap pendidikan inklusif dan trait kepribadian yang dapat mempengaruhi sikap, maka penulis ingin melihat pengaruh trait kepribadian big five terhadap sikap guru terhadap pendidikan inklusif di Sekolah Dasar Negeri Inklusi di Jakarta. Oleh karenanya, penulis memiliki pendapat bahwa trait kepribadian big five dapat memberikan pengaruh pada sikap guru terhadap pendidikan inklusif di Sekolah Dasar Negeri Inklusi di Jakarta.

\section{Metode Penelitian}

Penelitian ini menggunakan metode penelitian kuantitatif. Populasi dalam penelitian ini adalah guru reguler yang menjadi wali kelas atau guru kelas yang mengajar di Sekolah Dasar Negeri Inklusi di Jakarta. Teknik pengambilan sampel yang digunakan dalam penelitian ini adalah probability sampling. Jenis teknik yang digunakan yaitu cluster sampling. Jumlah sampel dalam penelitian ini yaitu sebanyak 133 guru yang diperoleh dari 19 SDN Inklusi di Jakarta Selatan dan Jakarta Timur.
Pengumpulan data pada penelitian ini menggunakan instrumen berupa kuesioner. Penyebaran kuesioner dilakukan secara langsung dengan mendatangi sekolah yang menjadi sampel penelitian. Kuesioner pada penelitian ini terdiri dari dua instrumen penelitian, yaitu instrumen Big Five Inventory (BFI) yang dikembangkan oleh John (1991) dan telah diadaptasi bahasa dan budaya oleh Neila Ramdhani (2012) yang digunakan untuk mengukur trait kepribadian. Instrumen BFI diukur melalui dimensi openness to experience, conscientiousness, extraversion, agreeableness dan neuroticism.

Sementara itu, instrumen Multidimensional Attitudes toward Inclusive Education (MATIES) yang dikembangkan oleh Mahat (2008) digunakan untuk mengukur sikap guru terhadap pendidikan inklusif. Instrumen MATIES diukur melalui dimensi afektif, kognitif, dan perilaku.

Berdasarkan hasil uji validitas menunjukkan bahwa terdapat 15 item pada instrumen MATIES yang layak digunakan untuk penelitian, sedangkan pada instrumen BFI terdapat 37 item yang layak digunakan untuk penelitian. Koefisien reliabilitas pada skala sikap guru terhadap pendidikan inklusif yaitu 0,96 dan pada skala BFI untuk masing-masing dimensi yaitu openness to experience $(0,92)$, conscientiousness $(0,89)$, extraversion $(0,90)$, agreeableness $(0,86)$ dan neuroticism $(0,88)$.

Uji statistik yang digunakan pada penelitian ini adalah analisis regresi linier ganda. Analisis ini digunakan untuk mengetahui bagaimana prediksi dimensi big five terhadap sikap guru terhadap pendidikan inklusif.

\section{Hasil Penelitian dan Diskusi}

Berdasarkan gambaran subjek penelitian, diketahui bahwa responden pada penelitian ini didominasi oleh jenis kelamin perempuan yaitu sebanyak 107 subjek (80,5\%), sedangkan subjek dengan jenis kelamin laki-laki yaitu sebanyak 26 subjek $(19,5 \%)$.

Kemudian berdasarkan usia, subjek penelitian didominasi oleh guru dengan rentang usia 51-60 tahun yaitu sebanyak 51 orang $(38,3 \%)$, kemudian rentang usia 21-30 tahun yaitu sebanyak 30 tahun $(22,6 \%)$, rentang usia 31-40 yaitu sebanyak 28 
orang $(21,1 \%)$, rentang usia 41-50 yaitu sebanyak 23 orang $(17,3 \%)$ dan rentang usia 61-70 sebanyak 1 orang $(8 \%)$.

Sementara itu, gambaran subyek berdasarkan pendidikan terakhir menunjukkan bahwa subjek penelitian didominasi oleh guru yang memiliki pendidikan terakhir Strata 1 (S-1) yaitu sebanyak 127 orang $(95,1 \%)$, kemudian jumlah subyek yang memiliki pendidikan terakhir Diploma 3 (D3) yaitu sebanyak 4 orang (3,0\%) dan Strata 2 (S2) memiliki jumlah yaitu 4 orang $(1,5 \%)$.

Pada penelitian ini juga diketahui bahwa mayoritas subyek penelitian belum pernah berinteraksi dengan penyandang disabilitas sebelum mengajar di sekolah inklusif, yaitu sebanyak 76 orang $(57,1 \%)$, sedangkan sebanyak 57 orang $(42,9 \%)$ sudah pernah berinteraksi dengan penyandang disabilitas sebelum mengajar di sekolah inklusif.

Selain itu dapat diketahui pula bahwa subjek penelitian didominasi oleh guru yang belum pernah mengajar ABK sebelum mengajar di sekolah inklusif yaitu sebanyak 111 orang (83,5\%), sedangkan subjek yang sudah pernah mengajar ABK sebelum mengajar di sekolah inklusif yaitu sebanyak 22 orang (16,5\%).

Mayoritas responden juga merasa fasilitas di sekolah inklusif tempat mereka mengajar belum memadai yaitu sebanyak 124 orang $(93,2 \%)$, sementara itu sebanyak 9 orang $(6,8 \%)$ merasa fasilitas di sekolah inklusif tempat mereka mengajar sudah memadai.

Hasil perhitungan juga diketahui bahwa jumlah subjek penelitian didominasi oleh guru yang tidak paham mengenai isi Peraturan Menteri Pendidikan Nasional yang membahas tentang pendidikan inklusif, yaitu sebanyak 91 orang $(68,4 \%)$. Sementara itu sebanyak 25 subjek penelitian $(18,8 \%)$ mengaku paham mengenai peraturan tersebut, serta sebanyak $17 \quad(12,8 \%)$ subjek penelitian memiliki jawaban lain di luar pilihan paham dan tidak paham.

Sementara itu, berdasarkan kepercayaan diri guru dalam mengajar ABK di kelas inklusif, sebanyak 71 subjek penelitian $(52,4 \%)$ merasa percaya diri dalam mengajar $\mathrm{ABK}$ di kelas inklusif, sebanyak 50 (37,6\%) subjek merasa tidak percaya diri, dan sebanyak 12 subjek (9\%) menjawab di luar opsi jawaban.

Berdasarkan perhitungan kategorisasi skor sikap guru terhadap pendidikan inklusif, menunjukkan bahwa subyek yang memiliki sikap yang positif terhadap pendidikan inklusif yaitu sebanyak 58 orang $(43,6 \%)$, sementara itu subjek yang memiliki sikap negatif terhadap pendidikan inklusi berjumlah lebih banyak yaitu 75 orang $(56,4 \%)$.

Uji hipotesis pada penelitian ini dapat diperoleh hasil sebagai berikut:

a. Korelasi product moment menunjukan nilai korelasi antara dimensi openness to experience, conscientiousness, extraversion, agreeableness dan neuroticism dengan sikap guru terhadap pendidikan inklusif dapat dilihat pada Tabel 1.

Berdasarkan Tabel 1, dapat dikatakan bahwa hanya dimensi conscientiousness dan extraversion yang memiliki $p$ value $<0,05$ artinya terdapat hubungan antara dimensi conscientiousness dan extraversion terhadap sikap guru terhadap pendidikan inklusif.

b. Uji anova menunjukan nilai $\mathrm{p}=0,133$ lebih besar daripada nilai $\alpha=0,05$. Berdasarkan kriteria pengujian, Ha diterima dan Ho ditolak apabila nilai $\mathrm{p}<0,05$, sementara itu $\mathrm{Ha}$ ditolak dan Ho diterima apabila nilai $\mathrm{p}>0,05$. Tabel 2 merupakan hasil perhitungan uji Anova analisis regresi ganda. 
Tabel 1. Korelasi Product Moment

\begin{tabular}{ccc}
\hline Variabel & Sig. $(\mathbf{p})$ & $\boldsymbol{\alpha}$ \\
\hline $\begin{array}{c}\text { Sikap guru terhadap pendidikan } \\
\text { inklusif dan openness }\end{array}$ & 0,133 & 0,05 \\
\hline $\begin{array}{c}\text { Sikap guru terhadap pendidikan } \\
\text { inklusif dan conscientiousness }\end{array}$ & 0,006 & 0,05 \\
\hline $\begin{array}{c}\text { Sikap guru terhadap pendidikan } \\
\text { inklusif dan extraversion }\end{array}$ & 0,037 & 0,05 \\
\hline $\begin{array}{c}\text { Sikap guru terhadap pendidikan } \\
\text { inklusif dan agreeableness }\end{array}$ & 0,386 & 0,05 \\
\hline $\begin{array}{c}\text { Sikap guru terhadap pendidikan } \\
\text { inklusif dan neroticism }\end{array}$ & 0,104 & 0,05 \\
\hline
\end{tabular}

Tabel 2. Uji Anova Analisis Regresi Ganda

\begin{tabular}{cccccc}
\hline Model & Sum of Square & df & $\begin{array}{c}\text { Mean } \\
\text { Square }\end{array}$ & F & \multirow{2}{*}{ Sig. } \\
\cline { 1 - 4 } Regression & 4,663 & 5 & 0,933 & & \\
\cline { 1 - 4 } Residual & 64,996 & 127 & 0,512 & & \\
\cline { 1 - 4 } Total & 69,659 & 132 & & & 0,113 \\
\hline
\end{tabular}

Berdasarkan tabel di atas, dapat dikatakan bahwa Ha (hipotesis alternatif) ditolak, dan Ho (hipotesis nol) diterima, artinya tidak terdapat pengaruh dimensi openness to experience, conscientiousness, extraversion, agreeableness dan neuroticism dengan sikap guru terhadap pendidikan inklusif.

Berdasarkan hasil penelitian yang diperoleh dari uji korelasi, hanya terdapat dua dimensi kepribadian yang memiliki korelasi yaitu dimensi conscientiousness dan extraversion. Dimensi openness to experience, agreeableness dan neuroticism menunjukkan tidak memiliki korelasi.

Berdasarkan hasil penelitian menggunakan analisis regresi, diperoleh hasil penelitian yang menunjukkan bahwa tidak terdapat pengaruh trait kepribadian openness to experience, conscientiousness, extraversion, agreeableness dan neuroticism secara simultan terhadap sikap guru terhadap pendidikan inklusif di sekolah dasar negeri inklusi di Jakarta.

Berdasarkan hasil penelitian Todorovic, dkk (2012) dimensi kepribadian openness memiliki korelasi yang positif dengan sikap guru terhadap pendidikan inklusif, hal tersebut tidak sejalan dengan hasil penelitian ini. Dimensi openness to experience dalam penelitian ini tidak memiliki korelasi dan pengaruh terhadap sikap guru terhadap pendidikan inklusif namun dimensi ini memiliki arah hubungan yang positif.

Dimensi conscientiousness dalam penelitian Todorovic, dkk (2012) tidak mempunyai korelasi yang positif terhadap sikap guru terhadap pendidikan inklusif. Pada penelitian ini dimensi conscientiousness juga memiliki korelasi dan arah hubungannya negatif. Hal tersebut dapat terjadi karena dimensi conscientiousness mendeskripsikan orang-orang yang teratur, terkontrol, terorganisasi, ambisius, terfokus pada pencapaian diri dan memiliki disiplin diri (Feist \& Feist, 2011). Menurut Todorovic, dkk (2012) seseorang yang mempunyai dimensi conscientiousness secara dominan ditandai oleh kompetensi, ketertiban, kewajiban, pencapaian, disiplin diri dan kecekatan. Jika mereka tidak memiliki informasi yang cukup tentang jenis ketidakabsahan tertentu, atau beberapa kesulitan perkembangan lainnya, mereka tidak akan melakukan apa pun sampai mereka mengetahui informasi yang akurat dan yang dapat dipercaya tentang bagaimana fungsinya. Hal tersebut juga sejalan dengan gambaran subjek mengenai pemahaman peraturan Menteri Pendi- 
dikan tentang Pendidikan Inklusif, terdapat 91 subjek $(68,4 \%)$ yang tidak paham dengan peraturan tersebut.

Dengan demikian, ketika subjek tidak memiliki pemahaman yang cukup terhadap program pendidikan inklusif, maka subjek tidak menerapkan metode pembelajaran yang sesuai dengan pendidikan inklusif. Ketika siswa berkebutuhan khusus semakin diajarkan untuk mengerjakan sesuatu yang tidak mereka pahami atau sanggupi, maka mereka dapat terbebani. Namun dalam penelitian ini dimensi conscientiousness tidak memiliki pengaruh terhadap sikap guru terhadap pendidikan inklusif.

Dimensi extraversion juga memiliki korelasi dan arah hubungannya negatif. Extraversion ditandai dengan semangat dalam menjalin hubungan dengan orang lain, tegas dan asertif dalam bersikap. Individu akan memiliki sikap yang tegas terhadap sesuatu dan akan menyatakan tidak setuju jika mereka tidak setuju (Goldberg dalam Ramdhani, 2012). Berdasarkan hal tersebut, individu akan bersikap tegas dan asertif terhadap sesuatu yang mereka setujui atau yang tidak mereka setujui dan sesuatu yang mereka dukung atau sesuatu yang mereka hindari. Dimensi extraversion dalam penelitian ini juga tidak memiliki pengaruh terhadap sikap guru terhadap pendidikan inklusif.

Pada penelitian ini dimensi agreeableness tidak memiliki korelasi namun memiliki arah hubungan yang positif. Dimensi ini mempunyai ciriciri ketulusan dalam berbagi, kehalusan perasaan, fokus pada hal-hal positif pada orang lain. Dalam kehidupan sehari-hari mereka tampil sebagai individu yang baik hati, dapat kerja sama, dan dapat dipercaya (Goldberg dalam Ramdhani, 2012). Guru akan kerjasama dalam melakukan hal-hal yang meningkatkan keefektifan dalam pembelajaran sehingga pendidikan inklusif dapat berjalan dan sesuai dengan tujuannya. Pada penelitian ini, dimensi agreeableness tidak memiliki pengaruh terhadap sikap guru terhadap pendidikan inklusif.
Selanjutnya dimensi neuroticism tidak memiliki korelasi terhadap sikap guru terhadap pendidikan inklusif namun arah hubungannya negatif. Dimensi neuroticism juga tidak berpengaruh terhadap sikap guru terhadap pendidikan inklusif.

Selain itu menurut Avramidis dan Norwich (2002 dalam Elisa dan Wrastari, 2013) faktorfaktor yang mempengaruhi sikap guru terhadap pendidikan inklusif yaitu jenis hambatan siswa, gender guru, pengalaman dan pelatihan yang telah dilalui guru, tingkat kelas yang diajarkan, keyakinan guru dan lingkungan pendidikan yang mendukung proses berlangsungnya pendidikan inklusif.

Kemudian berdasarkan hasil perhitungan kategorisasi sikap guru terhadap pendidikan inklusif menunjukkan bahwa sebanyak 75 responden $(56,4)$ memiliki sikap yang negatif terhadap pendidikan inklusif, sedangkan sebanyak 58 responden $(43,6 \%)$ memiliki sikap positif terhadap pendidikan inklusif. Hal tersebut menunjukkan bahwa lebih banyak guru yang memiliki sikap negatif terhadap pendidikan in-klusif, yang berarti akan menyebabkan rendahnya harapan bagi para murid berkebutuhan khusus serta dapat mengurangi kesempatan belajar murid dalam waktu yang lama (Forlin, Tait, Carroll, \& Jobling; Wilczenski, 1993 dalam Weng, dkk., 2015).

Sikap negatif yang dimiliki guru terhadap pendidikan inklusif dapat dipengaruhi oleh faktor belum pernah berinteraksi dengan anak berkebutuhan khusus sebelumnya, pengalaman mengajar, pemahaman peraturan Menteri, dan berbagai faktor lainnya. Hal tersebut ditunjukkan pada gambaran subjek bahwa terdapat 76 subjek $(57,1 \%)$ yang belum pernah berinteraksi dengan anak berkebutuhan khusus sebelumnya. Berdasarkan pengalaman mengajar, terdapat 111 subjek $(83,5 \%)$ yang belum mempunyai pengalaman mengajar anak berkebutuhan khusus. Dengan demikian, faktor-faktor tersebut mempengaruhi sikap mereka dan cenderung membentuk sikap yang negatif. 


\section{Kesimpulan}

Berdasarkan pengujian hipotesis secara statistik dari 133 responden, diperoleh kesimpulan bahwa tidak terdapat pengaruh trait kepribadian openness to experience, conscientiousness, extraversion, agreeableness dan neuroticism terhadap sikap guru terhadap pendidikan inklusif di sekolah dasar negeri inklusi di Jakarta.

\section{Daftar Pustaka}

Dinas Pendidikan Provinsi DKI Jakarta. (2015). Daftar Sekolah Penyelenggara Pendidikan Inklusi Provinsi DKI Jakarta. Bersumber dari http://disdik.jakarta.go.id/download/ DATA/PPDB2015/Sekolah\%20Inklusif\% 202015.p df. Diakses pada 5 Maret 2016

Elisa, S. \& Wrastari, A. T. (2013). Sikap guru terhadap pendidikan inklusi ditinjau dari faktor pembentuk sikap. Jurnal Psikologi Perkembangan dan Pendidikan, 2(1), 0110.

Gallego, A., \& Pardos-Prado, Sergi. (2013). The Big Five Personality Traits and Attitudes Towards Immigrants. Journal of Ethnic and Migration Studies.

Galovic, D., Brojcin, B., \& Glumbic, N. (2014). The attitudes of teachers towards inclusive education in vojvodina.

Norwich, B. (2002). International Journal of Inclusive Education. Kompasiana. Pendidikan inklusif: peluang bagi kualitas pendidikan anak dan remaja khusus. Retrieved from http://www.kompasiana.com/ernafit riatun/pendidikan-inklusif-peluang-bagikualitas-pendidikan-anak-dan-remajakhusus_54f6c8dca333116d5a8b4843. Diakses tanggal 26 Maret 2016

Mahat, M. (2008). The Development of A Psychometrically-Sound Instrument to Measure Teachers' Multidimesional Attittudes Toward Inclusive Education. International Journal of Spesial Education, 23(1), 82-92.
Mulholland, S. (2016). ADHD-Specific Knowledge and Attitudes of Teachers (ASKAT): Development and validation of a new research instrument. International Journal of Educational Research, 109-116.

Peraturan Menteri Pendidikan Nasional Republik Indonesia Nomor 70 Tahun 2009.

Ramdhani, N. (2012). Adaptasi Bahasa dan Budaya Inventori Big Five. Jurnal Psikologi

Rangkuti, A. A., \& Wahyuni, L.D. (2016). Modul Analisis Data Penelitian Kuantitatif berbasis Classical Test Theory dan Item Response Theory (Rasch Model). Prodi Psikologi Faklutas Ilmu Pendidikan Universitas Negeri Jakarta

Scoffier-Meriaux, S., Falzon, C., Lewton-Brain, P., Filaire, E., \& d'Arripe-Longueville, Fabienne. (2015). Big Five Personality Traits and Eating Attitudes in Intensively Training Dancers: The Mediating Role of Internalized Thinness Norms. Journal of Sports Science and Medicine.

Sobur, A. (2009). Psikologi Umum dalam Lintasan Sejarah. Bandung: CV Pustaka Setia.

Suc, L., Bukovec, B., Zveglic, M., \& Karpljuk, D. (2016). Primary School Teacher's Attitudes towards Inclusive Education in Slovenia: A Qualitative Exploration. Journal of Universal Excellence.

Sugiyono. (2014). Metode Penelitian Kuantitatif, Kualitatif, dan R\&D. Bandung: Alfabeta.

Todorovic, J., Stojiljkovic, S., Djigic, G., \& Ristanic, S. (2012). Basic Personality Dimensions and the Attitudes of Primary and Secondary School Teachers towards Inclusive Education. Journal of Educational Sciences \& Psychology, 2, 66-75. 
Tsakiridou, H., \& Polyzopoulou, K. (2014). Greek Teachers' Attitudes toward the inclusion of students with special educational needs. American Journal of Educational Research, 2(4), 208-218.

UNESCO. Barriers to inclusive education. Retrieved from http://www.unescobkk. org/education/inclusive-education/what-isinclusive-education/barriers-to-inclusiveeducation/. Diakses pada tanggal 18 Maret 2016

Walker, R. J., \& Christopher, A. N. (2016). Timeof-Day Preference Mediates the Relationship Between Personality and Breakfast Attitudes. Personality and Individual Differences.
Weng, C. S., Walker, Z. M., \& Rosenblatt, K. (2015). Special Education Teachers' Attitudes toward Including Student with SEN in Mainstream Primary School in Singapore. Asia Pacific Journal of Development Differences. 2(1), 63-78.

Wilczenski, F. L. (1995). Development of a Scale to Measure Attitudes toward Inclusive Education. Educational and Psychological Measurement, 291-299. 